\title{
Appendicular diverticula in an infant: a bolt from the blue
}

\author{
Abdul Razak, ${ }^{1}$ Pankaj Kumar Mohanty, ${ }_{1}^{1}$ Anil Kumar Puralingegowda, ${ }^{2}$ \\ Ramachandra Chandrayya ${ }^{1}$
}

'Department of Neonatology, Manipal Hospital, Bangalore, Karnataka, India

${ }^{2}$ Department of Pediatric Surgery, Manipal Hospital, Bangalore, Karnataka, India

\section{Correspondence to} Dr Pankaj Kumar Mohanty, drpankajpaeds@gmail.com

Accepted 16 April 2014

\section{(a) CrossMark}

To cite: Razak A Mohanty PK

Puralingegowda AK, et al. BMJ Case Rep Published online: [please include Day Month Year] doi:10.1136/ bcr-2013-203384

\section{DESCRIPTION}

A 10-month-old inconsolable infant was admitted with irritability and non-bilious vomiting of 3 days duration. There was no abdominal distension; however, tenderness could be elicited in the right iliac fossa. Diagnosis could not be yielded after a careful clinical examination and investigations performed to rule out sepsis were turned out to be negative. An abdominal ultrasound was inconclusive except for a thickened bowel wall. In view of persistent and worsening symptoms a possibility of intestinal obstruction secondary to Ladd's band was thought of and hence proceeded with lapratomy. Lapratomy revealed appendicular diverticulum with secretion penting up in the diverticula giving an appearance of cyst for which appendectomy was performed (figure 1). Histopathology of the excised specimen revealed all the layers of the bowel with secretion in the diverticular lumen and neutrophilic infiltrate in the muscularis mucosa. The infant was discharged healthy postoperatively after 3 days.

Appendicular diverticula is one of the very rare diseases to suspect especially in ansymptomatic infant with abdominal problem where diseases such as intussusceptions, Ladd's bands, malrotation and volvulus, etc are more common. It is almost impos-

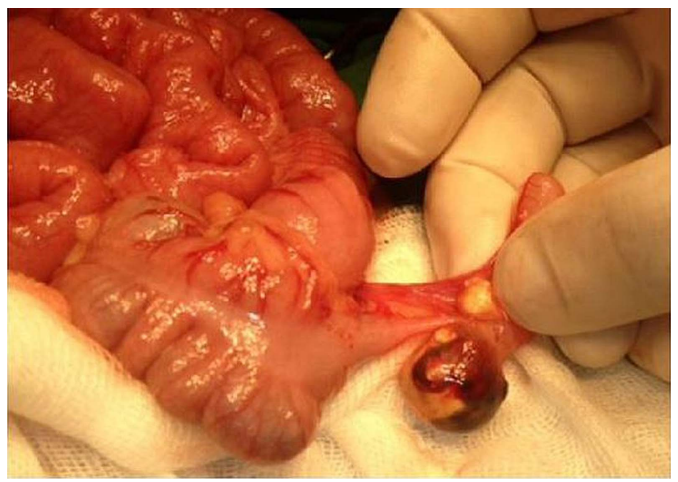

Figure 1 Appendicular divertculum in the lateral wall of the appendix with haemorrhagic spots and engorged vessels. Appendix appears to be normal. sible to ascertain until and unless the Pandora's box is explored. There have been few case reports on adults, ${ }^{1-3}$ and all the authors have one thing in common, 'a surprise', an uncertainty of disease, which is the same in our case too. The type of diverticula in our infant can be classified as type 1, where the appendix is normal and the diverticulum is inflamed. ${ }^{1}$ It can also be classified as congenital because of existence of all bowel wall layers. ${ }^{1}$ The incidence is reported to be $0.0014 \%$ in congenital form. ${ }^{2}$ Congenital diverticula are often solitary and found on the antimesenteric border compared with acquired ones, which are often multiple and located on the mesenteric border. The high risk of perforation of inflamed diverticula is fourfold compared with appendicitis increases the morbidity and mortality. ${ }^{2}$

\section{Learning points}

- Appendicular diverticulum can present during infancy and a high index of suspicion should be kept if preliminary investigations are non-contributory.

- Appendectomy to be performed in an appendicular diverticulum in a symptomatic infant.

Contributors AR has written the manuscript. PKM, AKP and RC have modified the article.

Competing interests None.

Patient consent Obtained.

Provenance and peer review Not commissioned; externally pee reviewed.

\section{REFERENCES}

1 Sreeramulu PN, Agrawal PV, Venkatachalapathy TS. Appendicular diverticulosis: a case report. Int J Biomed Adv Res 2012;03:595-6.

2 Hafeezuddin, Parveen B. Appendicular diverticulosis. Int I Pathol 2012;10:79-81.

3 Nagaraja R, Jagadish, Rommel, et al. Appendicular diverticulosisa diagnostic surprise. Internet J Surg 2008;20:1. 


\section{Images in...}

Copyright 2014 BMJ Publishing Group. All rights reserved. For permission to reuse any of this content visit http://group.bmj.com/group/rights-licensing/permissions.

BMJ Case Report Fellows may re-use this article for personal use and teaching without any further permission.

Become a Fellow of BMJ Case Reports today and you can:

- Submit as many cases as you like

- Enjoy fast sympathetic peer review and rapid publication of accepted articles

- Access all the published articles

- Re-use any of the published material for personal use and teaching without further permission

For information on Institutional Fellowships contact consortiasales@bmjgroup.com

Visit casereports.bmj.com for more articles like this and to become a Fellow 